\title{
LESÃO MUCOSA A NEISSERIA SICCA
}

\section{EFRAIM CAMPOS}

Desejo, trazendo a luz essa observação, contribuir para a casuistica e ao mesmo tempo fazer lembrar a possibilidade de leșóes condicionadas por este saprofita das cavidades mucosas.

Não me estenderei sobre citações bibliograficas, referentes à discussão da morfologia, cultura e patogenia do germen em questão, visto ser encontrado de maneira assaz completa nos tratados de uso corrente dos bacteriologistas.

\section{OBSERVAÇÃO}

P. A. - 23 anos - Casada - Brasileira - Parda - São Paulo.

Queixa - Ulcera no labio superior e tumefação na região lateral esquerda do pescoço ha um mês.

H. P. M. A. - Refere a paciente que ha cerca de um mês sófreu na mucosa do labio superior, na região correspondente ao phyltro uma pequena escoriação causada por inseto Periplaneta. Nos dias que sucederam-se formou-se aí uma crosta pequena de cor amarela, de tamanho de um grão de ervilha, que foi retirada, observando-se a presença de secreção purulenta abaixo da mesma. Formou-se nova crosta porém maior, tendo a paciente feito a mesma cousa, porém, agora notou "que existia ao redor. dela uma zona vermelho-viva que nos diàs posteriores aumentava cada vez mais de tamanho, porém, só formando crọsta no ponto primitivo. Esta área vermelhada não atingia a pele do lábio porém só progredia na zona mucosa. Nesta época o lábio superior tornou-se muito inchado e doloroso.

De 4 dias para cá acordou com um pouco de febre, dôr no pescoço não podendo rodar a cabeça porque tal movimento é doloroso, notando uma inguia (sic) na região parotido masseterina, do tamanho de um caroço de azeitona, muito dolorosa, que com o correr do tempo aumentou muito de volume ficando a região extremamente dolorosa, tanto à palpação como a movimentação da cabeça.

I. S. D. A. - Nada que possa apresentar interesse para o caso. Nega corrimento vaginal.

Ants. pessoais e hered. - Nega qualquer moléstia a não ser as comuns de infancia.

Ex. objetivo geral - Paciente parda - aparentando a idade que tem decubito indiferente - fácies boa - psiquismo bom - constituição esquelética boa - musculatura bem desenvolvida - pele quente e seca sem edema on circulação colateral. Pelos escassos, pilosidade pubiana obedecendo ao tipo feminino. Ganglios inguinais palpaveis, moveis, duros e indolóres.

Ex. especial - Cabeça e pescoço: Nada apresenta a não ser na cavidade bucal onde na superficie interna do labio superior ha uma lesão ulcerativa 
superficial vermelha, não sangrante, comprometendo somente a mucosa e se extendendo de modo simétrico, sobre os 2 lados da linha mediana e tendo no sentido transversal cerca de $2 \mathrm{cms}$. de extensão. Para dentro se extende até o sulco gengivo labial. No seu centro existe uma crosta de cor amarela que removida demonstrou a lesão nesse ponto, sendo de caráter supurativo e invadindo até o derma, o que foi respeitado nas demais zonas. No seu conjunto - labio superior está bastante edemaciado e doloroso. Boca nada apresenta dignó de nota.

Região parotido masseterina esquerda: Verifica-se a presença de um ganglio notavelmente aumentado de volume com peri-adenite extremamente dolorosa, sem flutuação, porém muito quente.

Exs. divs. aps. - Nada revelou digno de nota.

\section{DIAGNOSTICO}

Como não se pudesse firmar um diagnostico seguro a partir da observação clinica exclusiva, a paciente foi enviada ao Dr. Francia Martins e Ettore Rugai para exame bacteriologico e bacterioscopico do exudato, cujos resultados em duas analises sucessivas foi o seguinte: Colheita do material feita no Instituto Bacteriologico, por duas vezes, após lavagem prévia dạ ulceração com algodão e agua distilada. A retirada do material efetuada por escarificação e semeado em ágar sangue e ágar soro. A lamina para exame direto, corada pelo metodo de Gram, revelou a presença de alguns bacilos Gram negativos e positivos e diplococos Gram negativos intra e extracelulares.

Dos exames culturais, foi isolado um germen na primeira colheita: diplococo Gram negativo, assim como outros germens banais sem importancia. $Q$ diplococo foi identificado como Neisseria sica.

$\mathrm{Na}$ segunda colheita, somente foi identificado o Streptococcus viridans e mais os germens banais, acahando-se a doente muito melhor com o tratamento feito no intervalo das colheitas.

\section{COMENTARIOS}

A neisseria sica - von Lingelsheim, Bergey - é um coco Gram negativo, muito semelhante ao gonococo (Neisseria gonorrhoeae Trevisan), dele se diferençando pelos caracteres culturais. Fermenta a dextrose, maltose e levulose. Suas colonias são pequenas, duras e aderentes ao meio.

E' encontrada a Neisseria sicca nas vias respiratorias superiores, donde chamar-se tambem "Diplococcus pharingis siccus" (V. Lingelsheim), "Micrococcus pharyngis siccus" (Kutscher) etc. Eventualmente pode encontrar-se outras regiões, e, conforme cita Carvalho Lima em sua "Bacteriologia" 3.a ed., foi isolado por Schultz de um caso de endocardite vegetante e por C. Lima de varios casos de meningite. $O$ autor referido acima, tem isolado de varios casos de uretrite cronica do homem, confirmando-se dessa forma a possibilidade de se tornar patogenico um germen habitual do naso-faringe. 
O meu caso é interessante por se verificar a possibilidade de ser a N. sicca a causa do mal, pois a ulceração melhorou após um tratamento adequado, revelando no segundo exame só o. S. viridans, e curando-se logo em seguida. O S. viridans pode-se encontrar ocasionalmente na boca e epiderme, quer na flora normal quer produzindo infecções tipicas. A sua persistencia no segundo exame, com franca melhora dos sinais clinicos, induz-me a pensar ser ele no caso, um germen de associação.

Estabelecido o diagnostico foi instituido o tratamento pela sulfamico-pyridina (693) em doses decrescentes a partir de 3 grs. dia, tendo a paciente perfeitamente suportado 30 grs. de medicamento.

As melhoras foram notaveis, tendo desaparecido o edema, regredido as manifestações inflamatorias mucosas, obtendo a cura completa vinte dias após instituido o tratamento.

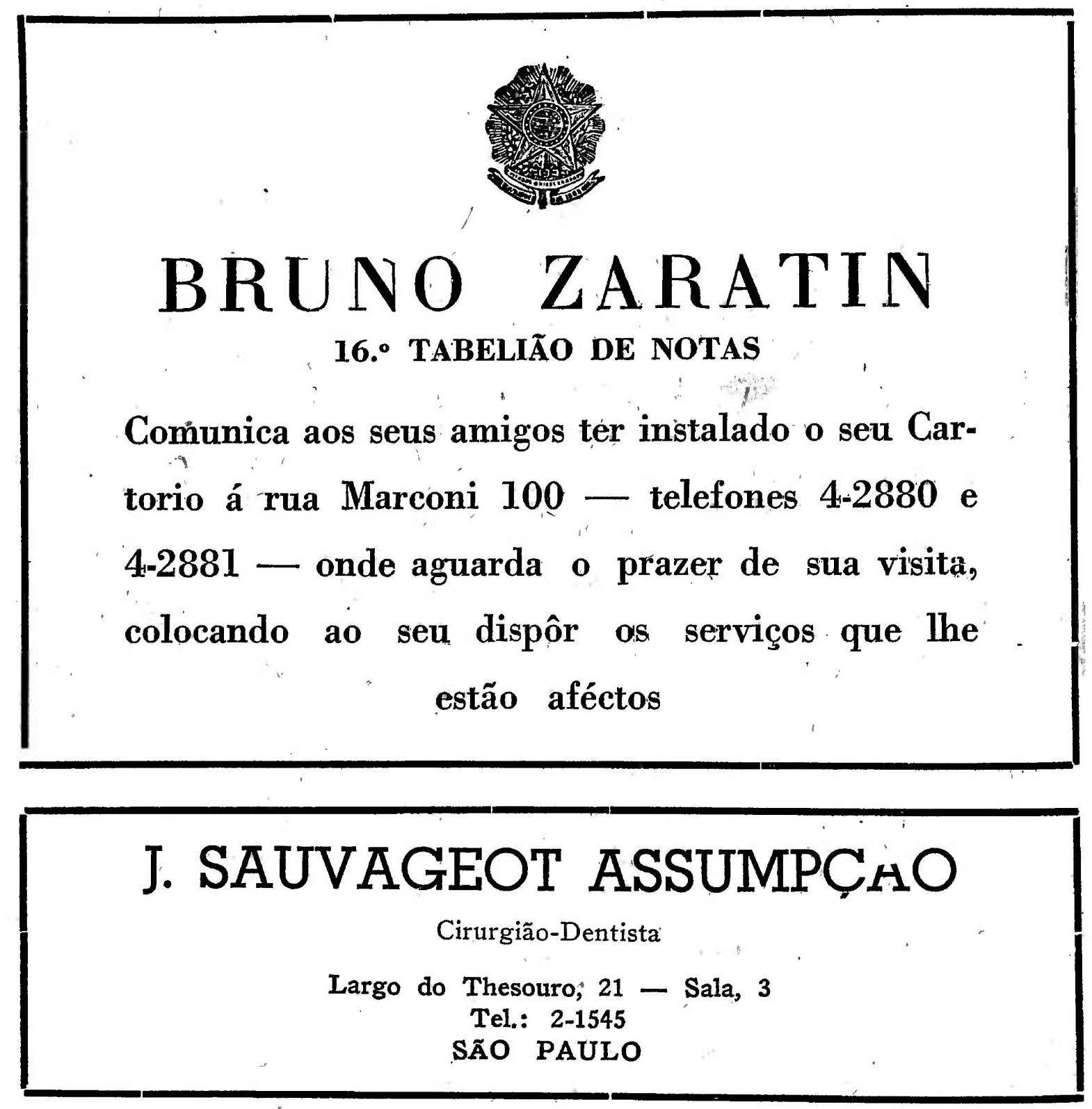




\section{ORIENTAÇÕES PARA O USO}

Esta é uma cópia digital de um documento (ou parte dele) que pertence a um dos acervos que fazem parte da Biblioteca Digital de Obras Raras e Especiais da USP. Trata-se de uma referência a um documento original. Neste sentido, procuramos manter a integridade e a autenticidade da fonte, não realizando alterações no ambiente digital - com exceção de ajustes de cor, contraste e definição.

1. Você apenas deve utilizar esta obra para fins não comerciais. Os livros, textos e imagens que publicamos na Biblioteca Digital de Obras Raras e Especiais da USP são de domínio público, no entanto, é proibido o uso comercial das nossas imagens.

2. Atribuição. Quando utilizar este documento em outro contexto, você deve dar crédito ao autor (ou autores), à Biblioteca Digital de Obras Raras e Especiais da USP e ao acervo original, da forma como aparece na ficha catalográfica (metadados) do repositório digital. Pedimos que você não republique este conteúdo na rede mundial de computadores (internet) sem a nossa expressa autorização.

3. Direitos do autor. No Brasil, os direitos do autor são regulados pela Lei n. ${ }^{\circ}$ 9.610, de 19 de Fevereiro de 1998. Os direitos do autor estão também respaldados na Convenção de Berna, de 1971. Sabemos das dificuldades existentes para a verificação se uma obra realmente encontra-se em domínio público. Neste sentido, se você acreditar que algum documento publicado na Biblioteca Digital de Obras Raras e Especiais da USP esteja violando direitos autorais de tradução, versão, exibição, reprodução ou quaisquer outros, solicitamos que nos informe imediatamente (dtsibi@usp.br). 